\title{
Transformative Pedagogy Through Strong Poetry
}

\author{
Carol M. Lee \\ University of Ottawa \\ clee185@uottawa.ca
}

\begin{abstract}
In No Return, a refugee story in poems, the author reflects on the critical stance of art, particularly, language as art. The anthology uses an eclectic set of methodological tools drawn from critical discourse and literary analyses, and as importantly, it incorporates critical pedagogy theory. This article consists of two parts. The first is a literary deconstruction of the introductory poem in the story. In part two, the author argues cogently that as researchers, educators, and creative writers we share collective responsibilities for the words we use and the stories which we tell; furthermore, the author reminds us that stories are the agents of pedagogy.
\end{abstract}

Keywords: refugee, pedagogy, art, critical stance, poetry, strong poetry

No Return is a refugee story told in poems. The opening imagery is of two crows in a snow storm watching from a tree branch that appears suspended and cut off from its trunk because of the wind and weather conditions. As readers, we know that the hidden parts of the branch are still connected to the tree. The metaphor evokes a sense of separation and a sense of the hidden. The height of the branch evokes a sense of danger, although from this remote position the crows can surveil the landscape even if they are cold and at the mercy of the storm. The separation that we sense between the tree and its branch is one we are meant to feel for the crows as well. Knowing that crows often live in extended families called murders ${ }^{\mathrm{i}}$, the image of the two crows, sitting alone, and furthermore, that they are the only ones still alive in their entire murder (family), is particularly poignant.

While there is no explicit mention of the word murder in the poem, the concept of murder---by way of the name for crow families---is an unstated, hidden, undercurrent running throughout the text. Knowing that the two crows are separated from their murder allows readers to make inferences about mother and daughter, the two refugees. The first inference is that the refugees are also enduring an unnatural and painful separation from their extended families and home. The second inference is that like the crows, the refugees' extended families---their murders---have, indeed, been murdered. The third inference is that like the crows who enact funerals for dead family members to better understand the cause of death and to assess possible danger and threat (Bradford, 2017), the refugees in this poem having witnessed their family's death, recognize an imminent threat to their own lives.

Although the situation is grave, it is not entirely hopeless either for the crows who are known for their problem-solving ability and adaptability, or for the refugees they represent. Hope is, however, fragile, ephemeral---almost airborne, and like a crow taking wing, a refugee's hope is in flight. 
While the crows metaphorically represent the mother and daughter refugees, they are also imbued with the mythical properties of Hugin (Thought) and Munin (Memory) (Lindow, 2002). In ancient Viking legends, the crows/ravens are emissaries of the Norse god Odin. Hugin and Munin's mythological purpose on earth is to be Odin's eyes and ears, and to report all that they see and hear to him. Accordingly, the refugees in this poem are also witnesses. While they must carefully consider a way through their own storm/trauma, they are also tasked with remembering experiences and what they see and hear. They are tasked with reporting to us, the readers, and to God.

For the above reasons, the 14 subsequent poems in No Return represent what the crows' have witnessed. The poems attempt to represent and report the trials, horrors and psychological conditions of being a refugee. The refugee story ends with a bittersweet poem about the experiences of immigration and transformation.

\section{Considering the Creative Art of Words}

\section{"Any human power can be resisted and changed by human beings. Resistance and change often begin in art and often in our art---the art of words.” (Le Guin, 2014)}

These poems ${ }^{\mathrm{ii}}$ and the story they convey call us as academic researchers, educators and creative writers to examine the critical functions of narrative and narrative poetry, and invite us to examine how language shapes what we think and how we think about what we think (Wittgenstein, 1974, p. 68 in Leggo, 2012). Acknowledging the power of language to shape thinking becomes a call to us to be responsible for the words we use and the stories we tell with them because they are the agents of pedagogy.

Consider the meaning of the word "refugee" in Canada. It can have several meanings associated with a range of emotional, visceral and cerebral responses. The word might evoke empathy, or speak to a collective imaginary (Anderson, 1983) in which we, as Canadians, see ourselves as a people who are tolerant and accepting of multi-culturalism even when our actions betray us (Mackey, 2012). For others, the word may describe, unfortunately, an "undesirable" other (Gomez, 2017).

In each of these conceptualizations, the word "refugee" carries with it a context and a narrative that gives the word one of its nuanced meanings. If one pauses to think about that for a moment, it is humbling to realize that each of these meanings is first learned as a word in context through language development. When one hears or reads a new word, or encounters an old one, the context of the word is examined (Barsalou, 2016), if only momentarily, to determine what meaning was intended and what meaning should be taken. In that moment, a specific new semantic is learned or an old one is relearned explicitly or implicitly, in what John Dewey referred to as cultural transmission (1916). If readers and listeners learn meaning from words in context, then one could say that writers and speakers teach the meaning of words with context (and narratives) as they use them. Interestingly, when a speaker or writer uses a known word in a unique or specific context, the meaning previously learned is altered, if ever so slightly, by that context (Derrida, 1970). Seen in this light, the many ordinary conversations we have each day are actually very complex and nuanced teaching/learning exchanges; they are conversations that 
involve the negotiation and understanding of very specific meanings between participants. One could generalize and say that every word and every meaning of that word is one that has been shared (taught and learned) with at least one other person (Vygostsky, 1986). While a specific meaning may be accepted or rejected by the listener or reader, there is always a shared meaning that cannot be unshared, and cannot, perhaps, be unlearned. There is responsibility in all of us as speakers and especially in those of us who are writers to choose our words carefully---critically, and to be mindful of what we are teaching.

I reassert that words, because of the potential for both constructive and destructive meaning-making which they carry and teach through context and narrative, are the powerful agents at the core of pedagogy. "The art of words" (Le Guin, 1995), is for me, a creative production and reproduction of meaning in the service of the critical. In the following sections, Language as Method, Narrative as Copoiesis/Sympoiesis, and Pedagogy as Strong Poetry, I outline how in No Return the creative act synthesizes language, narrative, and pedagogy as a critical act.

\section{Language as Method}

Language is an important feature of No Return, as is story. The text constantly reminds the reader of the language mechanics being used to construct the poems. Sometimes it is explicit as in the poems: "A Memory", "Execution", and "Autumn Sunset." Sometimes, it is not so blatant. In these cases, words sometime play against conventional turns of phrase as in the poems: "The Party" and "Lines of Aggression." Sometimes words are sliced up to show their composition and forgotten history (Koppelman, 2015) as in the poem, "Learning to Read the Times." Sometimes homonyms and double entendre draw the reader's attention to a specific point as in the poems: "Left and No Rights" and "New Shoes." Sometimes word or syllabic repetitions cause the reader to stutter, forcing stops in the flow of thought to encourage a rethinking of an accepted logic, as in the three-part poem, "Tyranny of Circumstances for Ty, Anny, and Archy." Sometimes words are strung together to roll off the tongue effortlessly and in so doing, blend the conceptual overtones of one set of ideas with the next set and so on, as in the poem, "I Was."

Aside from words being agents of pedagogy, as I have defined them, Le Guin (2007) reminds us of the serious implications of language on others, saying "writing, whatever its medium, is made of words, and words are bodily, made with the body and the breath, received by the body, felt with the body, and the rhythms of words are bodily rhythms." Perhaps more than that she is reminding us too of the joy of language, of how its rhythms resonate and stir us, and how as creative writers, language intoxicates us with words, their power and magic.

\section{Narrative as Copoiesis/Sympoiesis}

Like Atlantis by Mark Doty (Doty, 1995), No Return is a narrative. It has a plot and tells a story in poems.

What makes a story is - you want to 'find out what happens next'. Like running...the cantputdowner type story [is], fast-paced, suspenseful. You don't see much scenery, running, or learn much. You run for the sake of running, the

pleasure and excitement. Then there is the story like walking, steady, and you fall 
into the flow of the gait and cover ground while seeing everything around you, scenery you may never have seen before; and the walk may end up somewhere you've never been. And there's the story like dancing, where the next movement keeps growing out of the last movement, but not in a straightforward way... if the dance is true to itself, all the movements are connected and every one follows from the last, not predictably, but inevitably. (Le Guin, 2007).

The poems in No Return are of the dancing variety, to use Le Guin's terminology.

Stories, because they often have a beginning, middle and end, can be mistaken as selfcontained units that are whole and complete, but this is not the case. Stories are always incomplete renderings (Munro, 1994)! A story is what the storyteller decides to foreground against the background of everything else. Discontinuity is what is foregrounded in No Return and it is just a fraction of what could be told about a refugee's condition.

Further, because so much information must be left out (not lost) in the telling of a story, the reader/listener must fill in the gaps the storyteller omits with her/his previously known information, understood societal norms, imagination, and many other processes (Iser, 1978, 1997, 2011) that Rosenblatt (1969) calls reader/writer transactions. In transacting with the story, the storyteller and reader/listener engage in a conversation---a dialogic (Bakhtin, 1988) not only with each other, but with the commonly held values and beliefs of their society. No Return challenges us to examine these values and to question whether our country is doing enough for refugees.

As partial and incomplete as stories are, they are, none-the-less, well suited to carrying large amounts of information, like detailed instructions, scenario-based conflict resolutions and collective memories (Habermas, 1987; Haraway \& Teubner, 1991). When the storyteller focuses the text on a foregrounded subject, he/she also filters out noise which can help a learner identify the key learning points and distinguish what is important from what is not. There are of course perils in this, but that discussion is outside the scope of this article. In keeping the narrative porous, the storyteller allows for multiple interpretations of the story to be held by individual readers/listeners/societies over time, while simultaneously preserving the narrative's main discursive thread as collective memory or as conflict resolution. Narrative as an agent of pedagogy is certainly more transparent and obvious than is language as an agent of pedagogy, but it is a scalar distinction, in my view, nothing more.

No Return is not only fragmentary as a story, it is only a single take on the experiences related. If this story was told again or by another, it would be recast differently depending on the day, the circumstances, the lessons to be learned/taught, or the emotions that must be felt as shared experience, and so on (Ferguson, 2013). Taken together, these are the processes of meaning making (copoiesis) that operate through the medium of story between storyteller and reader/listener and their society (Vygostsky, 1986).

The poems that stand as bookends in No Return carry the movement and transformational aspects of the story---the plot if you will. While the refugees are in flight in both poems, their personification changes from Crow to Canada Goose. Danger and discontinuity are exchanged for the safety and loneliness of a new start. This is represented by the image of a lone Canada Goose crying for its gaggle in the last poem. This cry is every bit as poignant as the image of the two crows separated from their murder in the first poem. In their new country, the refugees have 
little hope of returning home; there is no return. The refugees must somehow forge a different home, learn a new language, literally and figuratively, before their narratives can join the dialogues of their new communities.

\title{
Pedagogy as Strong Poetry
}

\begin{abstract}
"Do you realize, the phytolinguist will say to the aesthetic critic, 'that they couldn't even read Eggplant?' And they will smile at our ignorance, as they pick up their rucksacks and hike on up to read the newly deciphered lyrics of the lichen on the north face of Pike's Peak." (Le Guin, 1995)
\end{abstract}

Strong poetry, as the attribution at the beginning of this section by Ursula K. Le Guin suggests, is situated, dynamic, embodied and lively. It brings something new and fresh to something already known or to something not questioned. It is punchy and conceives of things that are almost dangerous to think about. Poetry, more than prose, can do this because while it demands the reader's strict attention, it doesn't ask for that attention for long periods of time.

For me, the language of the poem on the page, the narrative of the poem as story and history, and the dialogic of the poem as performance between me and others in the classroom are manifestations of "strong poetry" (Ng-A-Fook, Ibrahim, \& Reis, 2016, p. xix). Strong poetry is a term used to describe a pedagogy and curriculum that is joyful, meaningful, fresh, and innovative. My own understanding of the term, includes an element of the mundane that perhaps others may not accept. However, as the editor, Michael Holquist says in his introduction to Speech Genres and Other Late Essays (Bakhtin, 1988), "[a] common theme running throughout [Bakhtin's writings] is the need to exceed boundaries, while still recognizing that only through awareness of the very real restraints at work in mental and social life can we do so" (p. xix).

Strong poetry, for me, must be firmly anchored to what is already known (Vygostsky, 1978) as much as it must attach itself to transformation and artistry.

Vygotsky (2004) argued that developing a mastery of technology must accompany an expression of creative imagination-learning cannot be separated from and can indeed be enhanced by artistry and aesthetics...Even Dewey (1980) promoted aesthetics in education as transformative in helping people re-envision the status quo and challenge traditional structures of society. (Kafai, Fields, \& Searle, 2014, pp. 236-7).

Strong poetry makes demands on the meaning-making process between poet and listener/reader, in part because of its narrative brevity and density, and in part due to the literary conventions that have historically come to be associate with poetry. As Leggo (2012) points out, poetry is "filled with riddles, oxymorons, litotes, paradoxes, hyperbole, [and] all the devices of discourse" (p. 152). While I agree with Leggo that poetry can be tricky, poems, especially narrative poems, as agents of pedagogy are like underground waterways tapped by wells. The well gives water (meaning) at the earth's surface, and even when one chooses not to go below the surface to explore the depths of the well or the vastness of the waterways that feed it, those deeper and expansive waters of meaning are intrinsic to a strong poem and to strong poetry.

Like Carl Leggo, I am committed to strong poetry, meaning that "I am committed to exploring the intersections between creative practice and critical pedagogy, and creative 
pedagogy and critical practice" (Leggo, 2012, p. 146). For me, that means using all the tricks of language and story that I know to deconstruct and construct meaningful nuances with the words and plots I choose (creative practice) to challenge readers' thinking or rethinking (critical pedagogy), and to teach how crafting language (creative pedagogy) challenges us as writers to think critically about how we use language in our day-to-day (critical practice). Further, it is about how important framing and phrasing is in our discourse and dialogue, and how, in fact, the language we choose to think with and speak with can change our worlds for better or worse.

Finally, strong poetry, for me, is about embodying an understanding that it matters what words we choose to tell stories with, "[i]t matters what stories we tell to tell other stories with; it matters what concepts we think to think other concepts with" (Haraway, 2013, p. 138), and it is about critically enacting this understanding in all the small acts that make up a day, particularly those acts we teach through our words and our stories. 


\section{References}

Anderson, B. (1983). Imagined Communities. In Imagined Communities: Reflections on the Origin and Spread of Nationalism (pp. 48-60). London and New York. http://doi.org/10.2307/2056089

Bakhtin, M. M. (1988). Speech Genres and Other Late Essays. (V. W. McGee, C. Emerson, \& M. Holquist, Eds.), SubStance (Vol. 17). Austin: University of Nebraska Press. http://doi.org/10.2307/3684926

Barsalou, L. W. (2016). Situated Conceptualization. In M. H. Coello, Yann; Fischer (Ed.), Perceptual and Emotional Embodiment: Foundations of Embodied Cognition Volume 1 (pp. 18-47). New York: Routledge.

Bradford, A. (2017). Facts About Crows. Retrieved July 17, 2017, from https://www.livescience.com/52716-crows-ravens.html

Derrida, J. (1970). Structure, Sign, and Play in the Discourse of the Human Sciences. In Claude Lévi-Strauss Conference (Vol. 1, pp. 1-13).

Dewey, J. (1916). Democracy and Education: An Introduction to the Philosophy of Education.

Doty, M. (1995). Atlantis Poems. New York: Harper Perennial.

Ferguson, W. (2013). 419. Toronto: Penquin Books.

Gomez, A. (2017, May 4). Refugee admissions plummet under Donald Trump. USA TODAY, p. na.

Haraway, D. (2013). Sowing worlds: A seed bag for terraforming with earth others. In M. Grebowicz \& H. Merrick (Eds.), Beyond the Cyborg: Adventures with Donna Haraway (pp. 137-146). New York: Columbia University Press.

Iser, W. (1978). Review of The Act of Reading: A Theory of Aesthetic Response. Baltimore: Johns Hopkins University.

Iser, W. (1997). The Significance of Fictionalizing. Anthropoetics, 3(2), 381-383. http://doi.org/10.1111/j.1474-919X.1947.tb04155.x

Iser, W. (2011). The Reading Process: A Phenomenological Approach. In S. Towheed, R. Crone, \& K. Halsey (Eds.), The History of Reading: A Reader (pp. 80-92). London: Routledge.

Kafai, Y., Fields, D., \& Searle, K. (2014). Electronic Textiles as Disruptive Designs: Supporting and Challenging Maker Activities in Schools. Harvard Educational Review, 84(4), 532-556565. http://doi.org/http://dx.doi.org.proxy.bib.uottawa.ca/10.17763/haer.84.4.46m737237021478 $\underline{3}$

Koppelman, N. (2015). Blind Spot: Patterns of Meaning and the Metaphor of Mobility. Phi Kappa Phi Forum, 95(4), 4-8.

Cultural and Pedagogical Inquiry, Fall 2017, 9(2), pp. 19-26

ISSN 1916-3460 C 2017 University of Alberta

http://ejournals.library.ualberta.ca/index.php/cpi/index 
Le Guin, U. K. (1995). The author of the acacia seeds: and other extracts from the Journal of the Association of Therolinguistics. In The compass rose (Paperback, p. 271). Harper Voyager. Retrieved from http://interconnected.org/home/more/2007/03/acacia-seeds.html

Le Guin, U. K. (2007). What Makes a Story. Retrieved July 19, 2017, from http://www.ursulakleguin.com/WhatMakesAStory.html

Le Guin, U. K. (2014). National Book Foundation Medal for Distinguished Contribution to American Letters Acceptance Speech. National Book Foundation. Retrieved from http://www.ursulakleguin.com/MenuContentsList.html\#WorkOnsite

Leggo, C. (2012). Living Language: What Is a Poem Good For? Journal of the Canadian Association for Curriculum Studies, 10(1), 141-160. Retrieved from http://citeseerx.ist.psu.edu/viewdoc/download?doi=10.1.1.817.7021\&rep=rep1\&type=pdf

Lindow, J. (2002). Norse Mythology: A Guide to Gods, Heroes, Rituals, and Beliefs (Paperback). New York: Oxford University Press. Retrieved from https://books.google.ca/books?id=KlT7tv3eMSwC\&printsec $=$ frontcover\&source $=$ gbs na vlinks_s\&redir_esc $=\mathrm{y} \# \mathrm{v}=$ onepage $\& \mathrm{q} \& \mathrm{f}=$ false

Mackey, E. (2012). Tricky Myths: Settler Pasts and Landscapes of Innocence. In N. Neatby \& P. Hodgins (Eds.), Settling and Unsettling Memories. Toronto: University of Toronto Press.

Munro, A. (1994). Carried Away. In Open Secrets (pp. 3-51). Toronto: McClelland \& Steward.

Ng-A-Fook, N., Ibrahim, A., \& Reis, G. (2016). Provoking Curriculum Studies Strong poetry and arts of the possible in education. New York: Routledge.

Rosenblatt, L. M. (1969). Towards a transactional theory of reading. Journal of Literacy Research, 1(1), 31-49. http://doi.org/10.1080/10862969609546838

Vygostsky, L. S. (1978). Interaction between learning and development. In Gauvain \& Cole (Eds.), Readings on the development of children (pp. 34-40). New York: Scientific American Books. Retrieved from http://www.colorado.edu/physics/phys4810/phys4810_fa08/4810_readings/vygot_chap6.pdf

Vygostsky, L. S. (1986). Thought and Language. Cambridge: The MIT Press Cambridge. Retrieved from http://s-f-walker.org.uk/pubsebooks/pdfs/Vygotsky_Thought_and_Language.pdf

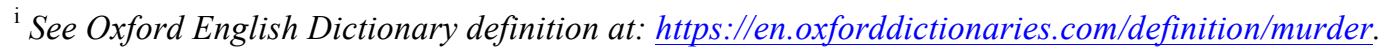
While the OED is uncertain of its origins, the first record of a "murder of crows" being used is dated to the 1400 s. ii This group of poems was inspired by the stories of a friend and next-door neighbor who migrated to Canada after WW2 from Estonia. Given the recent situation that forced many Syrians to seek refuge, my friend and I were struck by the similarities between her stories and those we read about in the news.
} 